\title{
Penurunan Intensitas Hujan Ekstrem di Bengawan Solo Hilir dan Hubungannya dengan ENSO
}

\author{
Heri Mulyanti ${ }^{*}$, Harjono ${ }^{2}$, dan Mrabawani Insan Rendra ${ }^{3}$
}

1Fakultas Sains dan Teknik, Universitas Bojonegoro Jl. Lettu Suyitno No.2 Bojonegoro 62171; e-mail: izzatafirdausa@gmail.com

2Fakultas Sains dan Teknik, Universitas Bojonegoro Jl. Lettu Suyitno No.2 Bojonegoro 62171

${ }^{3}$ Magister Perencanaan Wilayah dan Kota, Universitas Diponegoro

\begin{abstract}
ABSTRAK
Perubahan suhu global dapat mengubah sistem iklim, terutama presipitasi melalui peningkatan konveksi. Kondisi tersebut berpotensi terhadap kenaikan intensitas dan frekuensi hujan ekstrem. Hujan ekstrem merupakan sebab dari bencana hidrometeorologi seperti banjir, banjir bandang, dan kekeringan. Selain itu, pemanasan global berakibat pada El Nino/ Southern Oscillation (ENSO) dengan durasi kala ulang lebih pendek. ENSO berpengaruh terhadap iklim di sekitar wilayah monsunal Indonesia, terutama bagian timur. Jawa bagian timur mengalami kekeringan ekstrem ketika ENSO positif kuat. Penelitian ini bertujuan untuk: a) mengidentifikasi perubahan curah hujan ekstrem di Bengawan Solo Hilir tahun 1979-2017; b) menjelaskan kejadian hujan ekstrem saat fenomena ENSO (El Niño/ Southern Oscillation). Penelitian menggunakan data curah hujan harian dari 16 stasiun hujan di Bengawan Solo Hilir mulai 1979 - 2017 (39 tahun) yang telah diuji homogenitas dan konsistensi. Data tersebut digunakan untuk memperoleh indeks ekstrem hujan berupa Rx1hari, Rx5hari, P95, P99, dan intensitas hujan harian. Tren hujan monotonik dihitung menggunakan statistik Mann-Kendall, adapun besarnya perubahan dianalisis menggunakan uji Sen's slope. Hubungan antara hujan ekstrem dengan kejadian ENSO diketahui berdasarkan nilai korelasi Spearman-rank. Hasil penelitian menunjukkan bahwa sebagian besar stasiun hujan bagian timur-selatan mengalami penurunan hujan ekstrem berupa Rx1hari, P95, dan intesitas hujan harian (tren negatif) justru pada puncak musim hujan (Desember - Januari - Februari) dan transisi penghujan-kemarau (Maret-April-Mei). Penurunan hujan harian maksimum (Rx1hari) pada rentang 0,3 mm/tahun hingga 1,1 mm/tahun. Kejadian ENSO tidak otomatis berakibat pada intensitas hujan ekstrem skala harian. Indeks ENSO dapat digunakan untuk analisis indeks ekstrem dengan skala kumulatif antarmusim maupun antartahun. Hasil ini mengindikasikan bahwa variabel ENSO lebih tepat digunakan pada analisis kekeringan dan tidak berkaitan erat dengan bencana hidrometeorologi dalam skala pendek seperti banjir maupun banjir bandang.
\end{abstract}

Kata kunci: Bengawan Solo Hilir, ENSO, hujan ekstrem, intensitas

\begin{abstract}
Global temperature changes can alter climate system, especially precipitation through increased convection. These conditions potentially increase intensity and frequency of extreme rainfall. Extreme rain closely related to hydrometeorological disasters such as floods, flash floods, and drought. In addition, global warming results in shorter return period of El Nino / Southern Oscillation (ENSO). ENSO affects the climate around Indonesia's monsoonal regions, especially the eastern part. Eastern part of Java experienced extreme drought when ENSO was strongly positive. This study aims to: a) identify changes in extreme rainfall in Lower Bengawan Solo Basin in 1979-2017; b) explain the extreme rainfall events during the ENSO (El Niño / Southern Oscillation) phenomenon. The study used daily rainfall data from 16 rain stations in Bengawan Solo Downstream from 1979 - 2017 (39 years) which had been tested for homogeneity and consistency. The data is used to obtain extreme rainfall indexes: Rx1day, Rx5day, P95, P99, and daily rainfall intensity. Monotonic rain trends are calculated using the Mann-Kendall statistic, while the magnitude of the change is analyzed using the Sen's slope test. The relationship between extreme rain and ENSO events is known based on the Spearman-rank correlation value. The results showed that most of the east-south rain stations experienced a decrease in extreme rain especially Rx1day, P95, and daily rainfall intensity (negative trend) at peak of rainy season (December-January-February) and rainy-dry transition (March-April -May). Decrease in maximum daily rainfall (Rx1day) in the range of $0.3-1.1 \mathrm{~mm} /$ year. ENSO events do not automatically affect in the intensity of extreme rainfall on a daily scale. ENSO index can be used on analysis with cumulative scale, like interseason and interannual rainfall variability. These results indicate that ENSO variable is more appropriate for use in drought analysis but not closely related to short-scale hydrometeorological disasters such as floods or flash floods.
\end{abstract}

Keywords: Lower Bengawan Solo Basin, ENSO, extreme rainfall. intensity

Citation: Mulyanti, H., Harjono, Rendra, M.I. (2020). Penurunan Intensitas Hujan Ekstrem di Bengawan Solo Hilir dan Hubungannya dengan ENSO. Jurnal Ilmu Lingkungan, 18(1),73-81, doi:10.14710/jil.18.1.73-81 


\section{Pendahuluan}

Perubahan suhu global dapat mengubah sistem iklim global, terutama presipitasi/ curah hujan. Trenberth (2011) menyebutkan bahwa perubahan suhu global mengakibatkan peningkatan konveksi dan uap air di atmosfer. Kondisi tersebut dapat mempengaruhi siklus hidrologi terutama karakteristik hujan maupun kejadian hujan ekstrem. Hujan ekstrem sendiri erat kaitannya dengan bencana hidrometeorologi misalnya banjir, banjir bandang, dan kekeringan. Wilayah aliran sungai adalah area yang rentan terhadap kejadian hujan ekstrem.

Wilayah Sungai Bengawan Solo merupakan salah satu sistem ekologi wilayah sungai paling besar di Pulau Jawa dengan luas sekitar $19.778 \mathrm{~km}^{2}$ (Kementerian PU, 2019). Hulu sungai berada di Pegungungan Sewu, Provinsi Jawa Tengah kemudian berakhir di Ujungpangkah, Kabupaten Gresik, Provinsi Jawa Timur. Hilir sungai meliputi beberapa kabupaten, dengan wilayah terbesar berada di bagian utara Kabupaten Bojonegoro. Seluruh wilayah Kabupaten Bojonegoro (100\%) merupakan bagian dari Wilayah Sungai Bengawan Solo. Bagian selatan Bojonegoro berupa perbukitan dengan aliran sungai menuju Sungai Bengawan Solo.

Isu utama yang dihadapi Wilayah Bengawan Solo Hilir adalah ketersediaan air dan banjir. Banjir terjadi secara berkala pada wilayah Pacal - Soko (Kabupaten Bojonegoro sampai Tuban) yaitu sepanjang jalan utama di bagian utara kabupaten. Adapun bagian selatan cenderung kering dan mengalami masalah kekeringan saat musim kemarau (RPJMD Bojonegoro, 2015). Risiko kekeringan menjadi semakin tinggi karena prediksi Indonesia Climate Change Sectoral Map (ICSSR- Bappenas, 2010), Pulau Jawa mengalami penurunan curah hujan. Upaya awal menghadapi risiko tersebut dapat dilakukan dengan penilaian kecenderungan (tren) hujan. Hasil penilaian dapat dijadikan gambaran awal strategi mitigasi maupun adaptasi bagi masyarakat di Bojonegoro.

Wilayah monsunal, seperti Pulau Jawa, secara umum mengalami peningkatan frekuensi hujan ekstrem (Goswani, et al. 2006). Frekuensi hujan ekstrem terjadi di bagian barat Pulau Jawa cenderung bertambah (Siswanto dan Supari, 2015; Lestari, 2019) saat musim penghujan. Adapun wilayah Jawa bagian timur tidak menunjukkan perubahan curah hujan (Hidayat et al., 2019; Supari et al., 2012). Meskipun demikian, beberapa kabupaten di Jawa Timur memperlihatkan penurunan hujan ekstrem secara signifikan, yaitu Kabupaten Bojonegoro, Gresik, Ngawi, Sumenep, dan Ponorogo sejak 1981 - 2010 (Supari et al., 2012).

Fenomena perubahan suhu muka laut di Samudera Fasifik (El Nino/ Southern OscillationENSO) maupun Samudera Hindia dapat dijadikan alat untuk perkiraan variabilitas curah ujan antarmusiman terutama untuk wilayah monsunal (van den Hurk dan Jacob, 2009). Saat bulan September - Oktober terjadi tekanan tinggi di Indonesia. Apabila terjadi anomali suhu muka laut di Fasifik maka wilayah Indonesia akan mengalami penurunan konveksi. Dampaknya adalah penurunan curah hujan (Hidayat dan Ando, 2014). Pengaruh ENSO pernah diteliti oleh Narulita (2017) di Pulau Belitung yang mana ditemukan bahwa ENSO menyebabkan penurunan curah hujan signifikan bulan Juli Oktober. Curah hujan tahunan terpengaruh negatif kuat pada periode ENSO 2, 4, 5, 7, dan 8 tahun. Analisis hujan ekstrem dapat dijadikan bahan analisis risiko input air hujan.

Tujuan penelitian ini adalah: a) mengidentifikasi perubahan intensitas hujan ekstrem di Bengawan Solo Hilir tahun 1979-2017 dan b) menjelaskan kejadian hujan ekstrem saat kejadian El Nino/ Southern Oscillation (ENSO).

\section{Data dan Metode \\ 2.1. Data Indeks Ekstrem}

Penelitian untuk mengidentifikasi perubahan hujan ekstrem di Bengawan Solo Hilir menggunakan data harian 22 stasiun hujan di Kabupaten Bojonegoro. Stasiun tersebut dipilih berdasarkan persebaran data dan kelengkapan data. Pengamatan hujan dilakukan sejak Januari 1979 - 2017 dengan data kosong kurang dari $10 \%$ dari total data. Data diperoleh dari Unit Pelaksana Teknis Pengelola Sumber Daya Air (UPT PSDA) Bojonegoro, sebagai bagian dari Balai Besar Wilayah Sungai Bengawan Solo. Stasiun hujan tersebar pada bagian selatan Bojonegoro dan timur. Gambar.. menunjukkan persebaran stasiun hujan di Kabupaten Bojonegoro.

Pengujian data hujan dilakukan terlebih dahulu untuk memastikan keandalan data. Langkah uji meliputi kelengkapan data, autokorelasi, uji homogenitas, dan uji konsitensi. Data dikatakan lengkap jika dalam satu tahun hanya terdapat maksimal $10 \%$ data harian yang hilang. Rentang toleransi10\% memang cukup besar, akan tetapi jika menggunakan nilai toleransi yang rendah maka sebagian besar stasiun tidak dapat digunakan untuk analisis. Panjang data minimal adalah 25 tahun. Pengujian autokorelasi dilakukan untuk mengetahui dependensi data stasiun terhadap stasiun lainnya. Derajat kepercayaan yang digunakan adalah 95\% ( $\alpha=$ 0,05). Uji homogenitas dan konsistensi data menggunakan uji simultan (uji F) dan uji parsial (uji t). Data dibagi menjadi dua, yaitu sebelum terjadi perubahan (break) dan setelah terjadi perubahan. Varians dan rerata dua data tersebut dibandingkan untuk memperoleh nilai Fhitung dan thitung. Berdasarkan perhitungan, nilai Fhitung dan thitung lebih rendah dibandingkan dengan nilai tabel, sehingga tidak ada perubahan signifikan pada data. Hasil skrining mengindentifikasi hanya terdapat 16 stasiun yang dapat digunakan untuk analisis. Akan tetapi, untuk analisis Mann-Kendall dan kelerengan Sen, penelitian hanya menggunakan 14 stasiun karena terdapat 2 stasiun yang letaknya berdekatan. 
Tabel 1. Kriteria hujan ekstrem

\begin{tabular}{|c|c|c|}
\hline Indeks & Unit & Deskripsi \\
\hline Rx1hari & $\mathrm{mm}$ & $\begin{array}{l}\text { Curah hujan maksimum dalam waktu } \\
\text { sehari pada kurun } 3 \text { bulan atau tahunan }\end{array}$ \\
\hline Rx5hari & $\mathrm{mm}$ & $\begin{array}{l}\text { Curah hujan dalam waktu } 5 \text { hari } \\
\text { berturut-turut pada kurun } 3 \text { bulan atau } \\
\text { tahunan }\end{array}$ \\
\hline P95 & $\mathrm{mm}$ & $\begin{array}{l}\text { Total hujan lebih dari persentil } 95 \text { pada } \\
\text { kurun waktu } 3 \text { bulan atau tahunan }\end{array}$ \\
\hline P99 & $\mathrm{mm}$ & $\begin{array}{l}\text { Total hujan lebih dari persentil } 99 \text { pada } \\
\text { kurun waktu } 3 \text { bulan atau satu tahun }\end{array}$ \\
\hline SDII & $\mathrm{mm} /$ hari & $\begin{array}{l}\text { Perbandingan jumlah hujan harian } \\
\text { dengan hari hujan }\end{array}$ \\
\hline
\end{tabular}

Keterangan: indeks dimodifikasi dari ETCCDI
Identifikasi hujan ekstrem berdasarkan pada data curah hujan harian. Kriteria ekstrem tersebut diambil dari Expert Team on Climate Change Detection and Indices (ETCCDI, 2017). Kriteria hujan ekstrem terdapat pada tabel 1 . Indeks tersebut berasosiasi dengan ekstrem basah (R1max, R5max, P95, P99, dan SDII). Kondisi ekstrem kering dapat menggunakan kriteria R5max, yaitu curah hujan maksimal selama lima hari berturut-turut dalam satu bulan. Indeks yang dikembangkan oleh ETCCDI semula digunakan oleh Peterson (2005) kemudian diperkenalkan secara luas oleh Zhang et al. (2011).

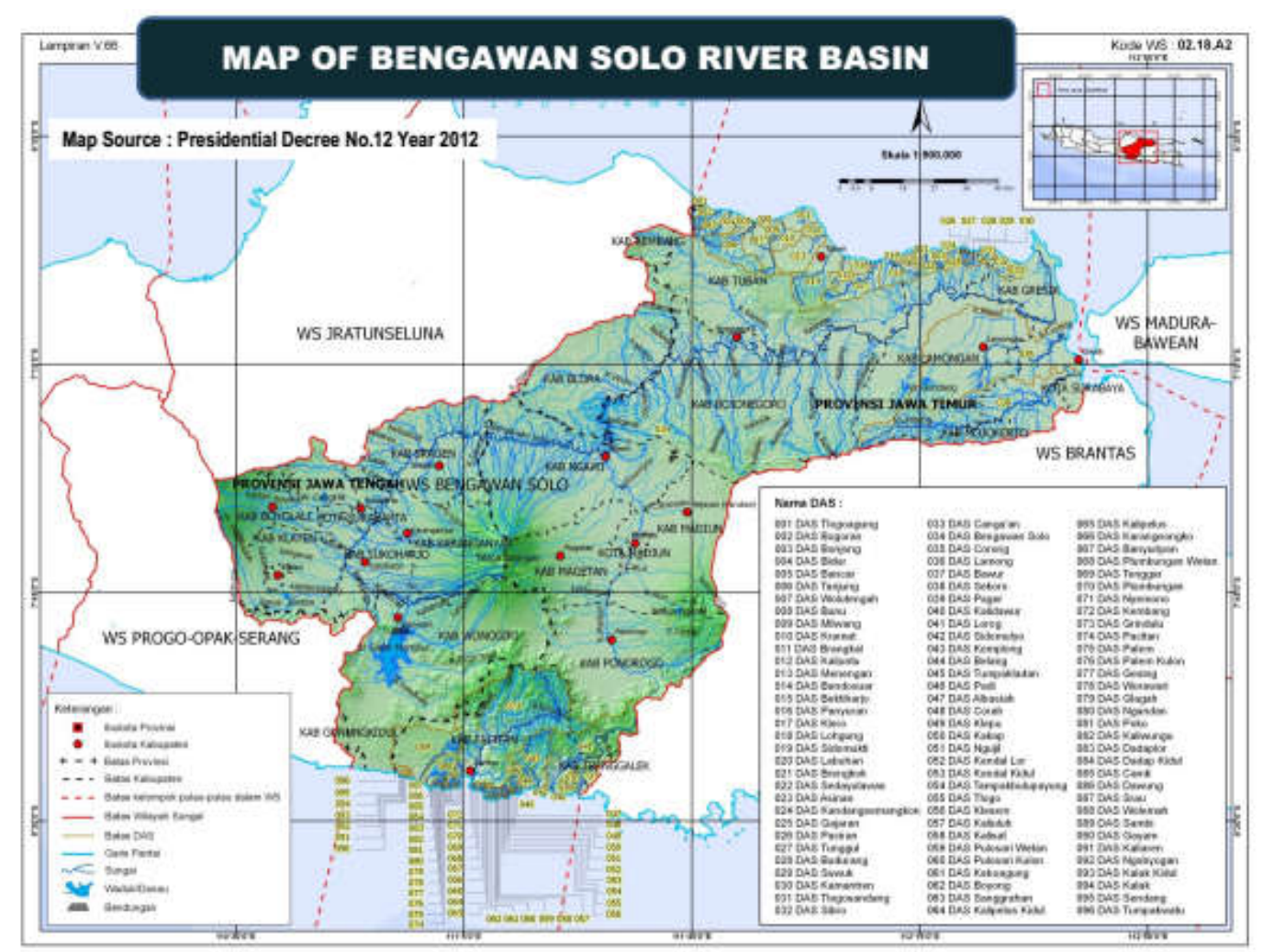

Gambar 1. Peta Wilayah Sungai Bengawan Solo. (Sumber: Dekrit Presiden No. 12 Tahun 2012).

\subsection{Data Indeks ENSO}

Identifikasi kejadian ENSO menggunakan indeks Sea Surface Temperature Anomaly (SSTA) Nino untuk region 3.4 (SSTA Nino 3.4) HadISST. Wilayah Nino 3.4 terletak pada $5^{\circ} \mathrm{LU}-5^{\circ} \mathrm{LS}$ dan $170^{\circ} \mathrm{BB}-120^{\circ} \mathrm{BB}$. Nino 3.4 paling banyak digunakan dalam analisis ENSO karena terletak di Pasifik tengah. Anomali suhu muka laut menggunakan tahun dasar 1981-2010. Data dapat diakses melalui www.esrl.noaa.gov/psd/gcos_wgsp/Timeseries/Nin o34/. Data re-analisis tersebut sudah berbentuk distribusi normal sehingga tidak perlu dilakukan transformasi data. Kejadian ENSO berdasarkan nilai SSTA Nino 3.4 HadISST rerata 3 bulan (3-month moving average) dengan nilai minimal $|0,5|$.

\subsection{Idenifikasi Perubahan Hujan Ekstrem}

Identifikasi perubahan hujan ekstrem (tren) monotonik menggunakan teknik Mann-Kendall. Uji Mann-Kendall termasuk dalam statistik nonparametrik sehingga tidak diperlukan data dengan distribusi normal. Statistik Mann-Kendall memberikan kesimpulan akhir berupa arah perubahan (positif atau negatif) dan derajat signifikansi. Hipotesis dasar digunakan adalah tidak ada perubahan $\left(\mathrm{H}_{0}\right.$ diterima) atau hipotesis alternatif yaitu $\mathrm{H}_{0}$ ditolak, yang berarti terdapat perubahan signifikan dari data. Besar kecilnya nilai perubahan dihitung menggunakan berdasarkan koefisien Sen's slope.

Uji Mann Kendal telah banyak digunakan untuk analisis perubahan unsur klimatologis seperti hujan dan temperatur. Metode ini cocok diterapkan untuk kejadian alam karena termasuk dalam statistik nonparametrik sehingga asumsi normalitas tidak diperlukan. Akan tetapi statistik nonparametrik tidak terlalu kuat/ kurang sensitif untuk menguji suatu data. Uji Mann-Kendall merupakan uji untuk mennetukan ada tidaknya perubahan data, baik positif maupun negatif. Tahapan uji meliputi 
perumusan hipotesis, penentuan tingkat signifikansi, menghitung nilai Z. Penelitian ini menggunakan hipotesis $\mathrm{H}_{0}$ : tidak terdapat kecenderungan dan $\mathrm{H}_{1}$ : terdapat kecenderungan. Tingkat signifikansi yang diinginkan adalah 95\% $(\alpha=0,05) . \mathrm{H}_{0}$ diterima jika nilai $\mathrm{Z}$ berada di antara titik kritis.

Uji Sen's slope hampir sama dengan teknik regresi linear maupun kudrat terkecil. Nilai yang dihasilkan oleh grafik Sen's adalah besarnya perubahan yang terjadi selama kurun waktu pengamatan. Besarnya perubahan dinotasi menggunakan nilai Q. Nilai Q positif berarti ada tren kenaikan.

Kecenderungan intensitas hujan ekstrem menggunakan jangka waktu tahunan dan musiman. Pembagian musim 3 bulanan antara lain: Maret-April-
Mei (MAM), Juni-Juli-Agustus (JJA), SeptemberOktober-November (SON), dan Desember-JanuariFebruari (DJF). Penelitian ini menggunakan perangkat lunak MAKESENS 1.0 yang dikembangkan oleh Institut Meteorologi Finlandia -Finnish Meteorological Institute (Salmi et al., 2002).

\subsection{Hubungan Hujan Ekstrem dengan ENSO}

Penilaian hubungan antara indeks hujan ekstrem dengan ENSO menggunakan teknik korelasi Spearman-Rank. Korelasi ini termasuk statistik nonparametrik sehingga tidak memerlukan asumsi data berdistribusi normal. Korelasi dihitung antara Rx1hari, Rx5hari dengan SSTA Nino 3.4.

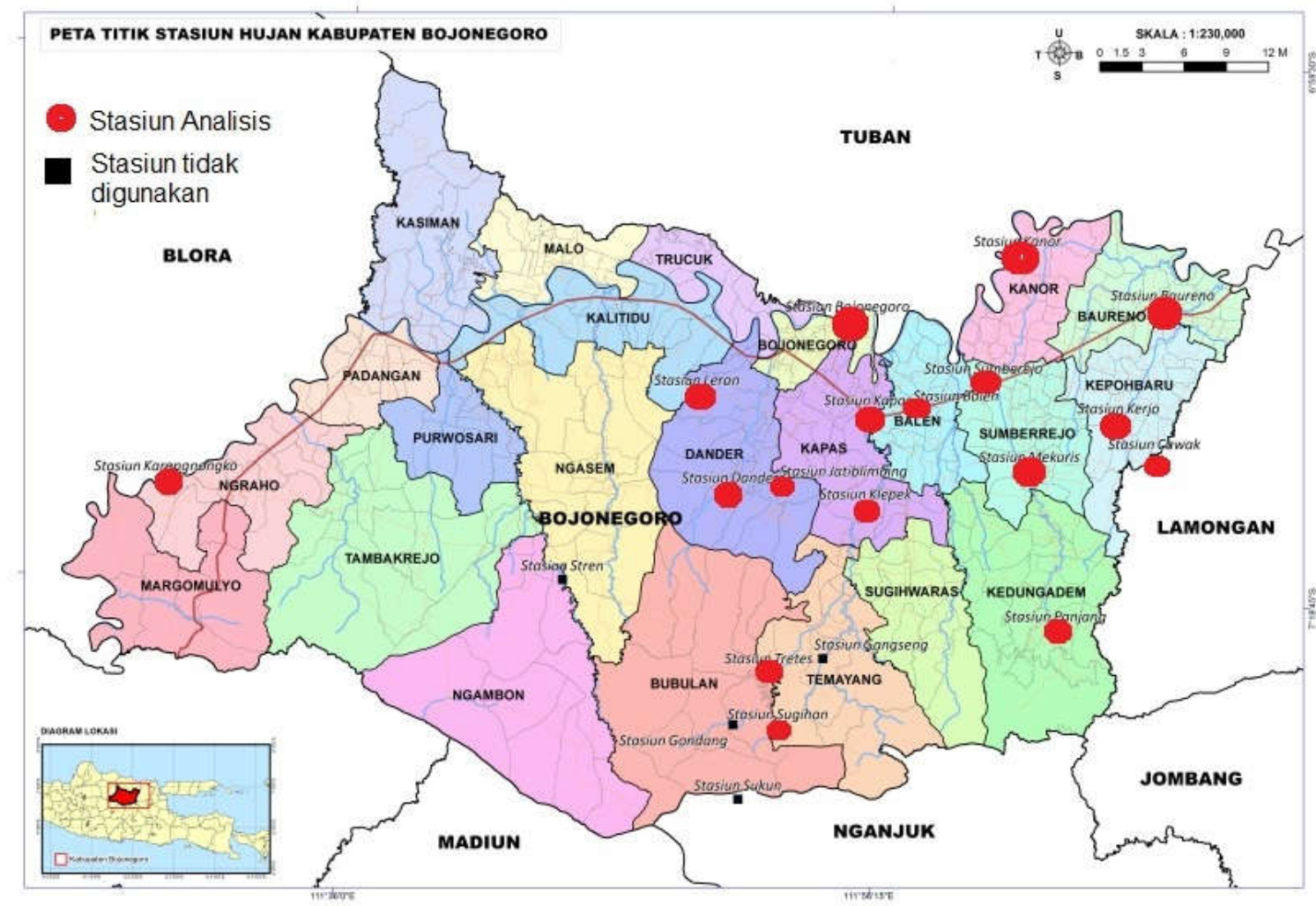

Gambar 2. Stasiun yang digunakan dalam analisis.

\section{Hasil dan Pembahasan}

\subsection{Hasil Uji Kehandalan Data}

Stasiun hujan Bengawan Solo Hilir yang berada di Kabupaten Bojonegoro terletak pada ketinggian 9 115 meter dpal dengan jumlah 22 lokasi (UPT PSDA Bojonegoro). Akan tetapi, 3 stasiun yaitu Simorejo, Gangseng, dan Nglambangan memiliki diskontinuitas pencatatan sehingga tidak dimasukkan dalam analisis homogenitas. Data hujan kosong ditemui pada 1981, 1983, dan 2001. Data hilang atau tidak tercatat dianggap sebagai data missing.

Kami menggunakan batas data hilang/ missing sebesar $10 \%$ dari total data hujan harian. Artinya, jika total data 39 tahun maka hanya diperbolehkan $<3,9$ tahun data hujan. Ambang batas 10\% digunakan karena sebagian besar stasiun dicatat secara kontinyu sejak 1983. Penempatan pos pada topografi yang relatif datar memungkinkan metode pengisian data hilang dapat menggunakan metode aritmatik dari stasiun sekitar. Uji persistensi dan uji konsistensi data hujan menunjukkan hanya 64\% stasiun dapat digunakan dalam penelitian lebih lanjut. Beberapa data tidak digunakan karena panjang data kurang dari 20 tahun.

Tabel 1 menunjukkan data stasiun hujan dan hasil uji curah hujan. Persebaran stasiun hujan dapat diamati pada Gambar 1.

Stasiun hujan yang digunakan memiliki panjang minimal 20 tahun untuk mengetahui kondisi iklim dan adanya perubahan. Beberapa stasiun yang memiliki panjang data kurang dari 20 tahun antara lain: Kendung, Padangan, dan Stren. Khusus untuk Stasiun 
Padangan, dokumentasi data tidak tersedia sejak tahun 2009 sehingga tidak digunakan dalam analisis. Uji persistensi data hujan dilakukan untuk mengetahui dependensi data hujan suatu stasiun menggunakan autokorelasi level 1 (nilai z=1,96). Data dependen tidak dapat digunakan dalam analisis lebih lanjut karena antar data terdapat hubungan berarti sehingga dikhawatirkan mengacaukan analisis. Beberapa stasiun dengan data bersifat dependen antara lain Leran dan Karangnongko. Dua stasiun tersebut tidak digunakan dalam analisis statistik seperti korelasi dan periodisistas karena selain data dependen juga tidak lolos uji $t$ dan atau uji $F$.

Uji konsistensi menggunakan grafik massa ganda dengan memperhatikan terjadinya perubahan data yang signifikan atau disebut dengan break. Meskipun stasiun Leran dan Karangnongko tidak lolos uji hujan, akan tetapi karena pertimbangan lokasi maka kedua stasiun tetap digunakan untuk analisis nonstatistik. Total stasiun digunakan dalam penelitian adalah 14 . Gambar 2 memperlihatkan stasiun yang digunakan untuk analisis hujan ekstrem. Distribusi stasiun hujan tidak merata, dengan pusat adalah bagian timur dari utara ke selatan. Bagian barat hanya terdapat satu stasiun pengukuran aktif (Karangnongko). Berdasarkan sebaran ini, maka penggunaan teknik spasial seperti interpolasi sulit dilakukan karena sebaran tidak seragam.

\subsection{Distribusi Hujan Ekstrem di Bengawan Solo Hilir}

Hujan ekstrem satu hari (Rx1hari) di Bengawan Solo Hilir ditampilkan pada Gambar 3. Fluktuasi curah hujan ekstrem harian memperlihatkan kecenderungan negatif. Rx1hari maskimal sebesar $270 \mathrm{~mm}$ terjadi tahun 1991 di Stasiun Leran. Nilai tersebut setara dengan curah hujan bulanan yang terdistribusi hanya dalam satu hari. Ekstrem tinggi ini dapat juga dikategorikan sebagai nilai 'jarang' dengan kala ulang $>20$ tahun (Villafuerte dan Matsumoto, 2015). Ekstrem tinggi ini seringkali menyebabkan data dianggap tidak konsisten. Hal ini juga berlaku untuk stasiun Leran, yang mana berdasarkan uji konsistensi, stasiun tersebut dinyatakan tidak konsisten.

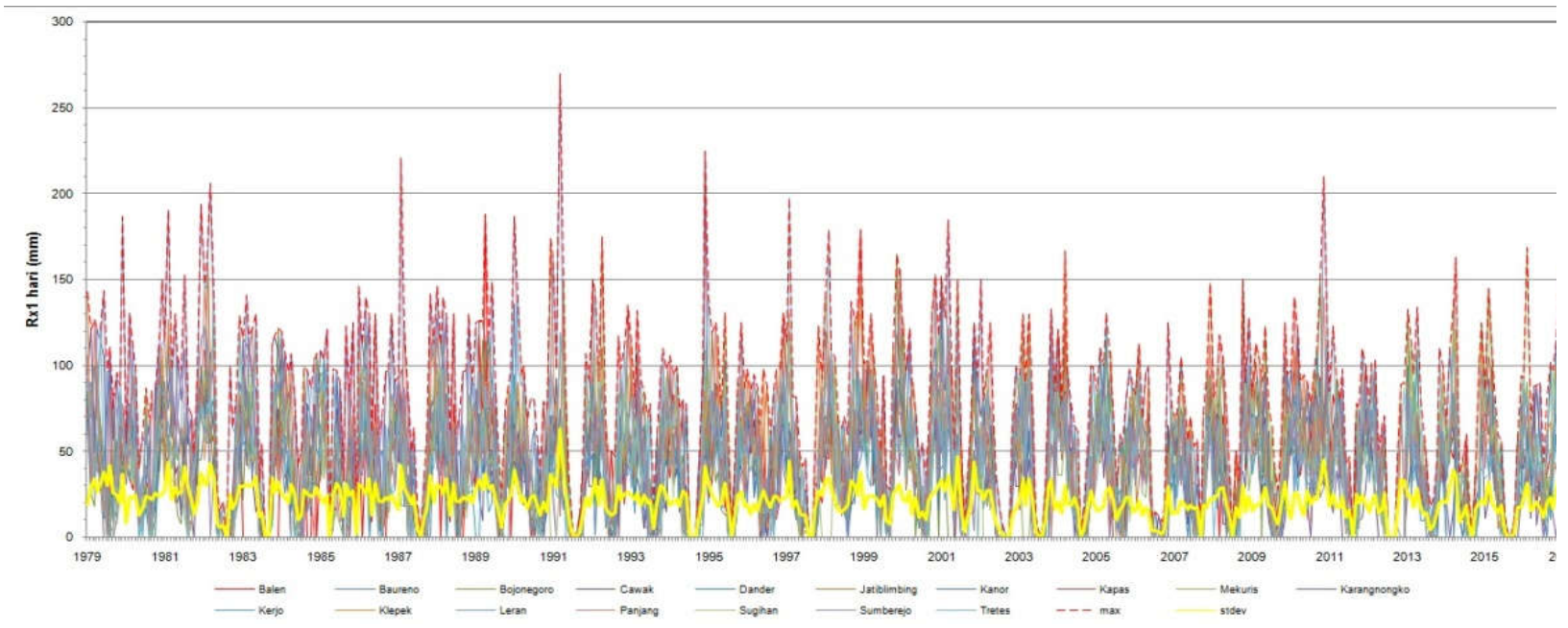

Gambar 3. Curah Hujan Harian Maksimum Stasiun-stasiun di Bengawan Solo Hilir 1979 - 2017. Garis putus-putus warna merah merupakan nilai maksimum, sedangkan garis warna kuning adalah nilai simpangan baku.

Kondisi tahun 1991 merupakan suatu anomali karena tahun 1991 tercatat sebagai tahun El Nino (Lestari et al., 2019) yang mana berpotensi menurunkan curah hujan di wilayah Jawa bagian Timur. Penurunan curah hujan akibat El Nino ternyata tidak berkaitan dengan hujan harian maksimum. Hujan harian maksimum lebih berkaitan dengan sirkulasi harian angin darat-latu maupun angin guung-lembah. Hasil ini tidak dapat dijelaskan oleh penelitian Aldrian (2008) yang mana hujan ekstrem di pesisir Jakarta waktu pagi hari disebabkan oleh akumulasi awan dari perairan serta sirkulasi harian berupa pergerakan angin darat-laut maupun angin gunung-lembah. Hujan tinggi dalam tempo sangat singkat justru berpotensi mengakibatkan banjir maupun banjir bandang.

\subsection{Tren Hujan Ekstrem}

Hujan ekstrem dapat dikategorikan menjadi ekstrem moderat dan ekstrem 'sangat'. Indeks yang dikeluarkan oleh ETCCDI termasuk dalam kategori moderat dengan kala ulang pendek. Tabel 2 merupakan hasil uji tren untuk semua stasiun. Stasiun yang mengalami penurunan signifikan antara lain Cawak, Jatiblimbing, Panjang, Sumberejo, dan Tretes. Kecenderungan hujan bernilai negatif memberi arti bahwa intensitas Rx1hari berkurang sejak 19792017. Hujan harian maksimum berkurang signifikan justru pada puncak musim penghujan (Des-Jan-Feb), di antaranya Stasiun Cawak, Jatiblimbing, dan Panjang. Ketiga stasiun tersebut berada di bagian selatan Kabupaten Bojonegoro dan rentan terhadap kekeringan. Adapun saat transisi penghujan-kemarau 
(Mar-Apr-Mei), stasiun Tretes dan Panjang juga memperlihatkan kecenderungan Rx1hari lebih rendah. Hujan harian maksimum skala tahunan dengan kecenderungan turun hanya dialami dua stasiun, yaitu Balen dan Cawak.

Penurunan tertinggi terjadi di Stasiun Jatiblimbing untuk musim penghujan utama (DJF) dengan nilai $Q$ sebesar $-1,1 \mathrm{~mm} /$ tahun. Kisaran penurunan hujan ekstrem harian antara 0,3 $\mathrm{mm} /$ tahun hingga $1,1 \mathrm{~mm} /$ tahun.

Nilai optimum harian erat kaitannya dengan perencanaan bangunan air seperti bendungan, waduk, dan irigasi. Semakin besar nilai harian maka bangunan air perlu kapasitas lebih besar. Akan tetapi, dengan adanya penurunan hujan ekstrem ini berarti bangunan air tidak membutuhkan kapasitas yang besar. Kondisi ini dapat berakibat buruk untuk wilayah dengan pertanian padi tadah hujan, yang mana air hanya diperoleh pada puncak musim penghujan. Bulan Desember - Januari - Februari merupakan saat hujan mencapai maksimum. Apabila hujan berkurang saat bulan-bulat tersebut maka total hujan tahunan dapat berkurang. Kondisi ini dapat mengancam ketersediaan air terutama pada wilayah yang rentan kekeringan. Pada sisi lain, penurunan kondisi ini juga dapat diartikan bahwa intensitas banjir bandang berkurang. Terkait dengan banjir bandang, perlu adanya analisis pelengkap berupa frekuensi hujan ekstrem yang berpotensi menyebabkan banjir bandang. Selain itu, data intensitas hujan perlu dilengkapi dengan hujan jamjaman (hourly rainfall data).

Tabel 2. Tren Hujan Ekstrem Rx1hari Bengawan Solo Hilir.

\begin{tabular}{|c|c|c|c|c|c|c|c|c|c|c|}
\hline \multirow{2}{*}{ Stasiun } & \multicolumn{2}{|c|}{ Tahunan } & \multicolumn{2}{|c|}{ MAM } & \multicolumn{2}{|c|}{ JJA } & \multicolumn{2}{|c|}{ SON } & \multicolumn{2}{|c|}{ DJF } \\
\hline & $\mathbf{Z}$ & $\mathbf{Q}$ & $\mathbf{Z}$ & $\mathbf{Q}$ & $\mathbf{Z}$ & $\mathbf{Q}$ & $\mathbf{Z}$ & $\mathbf{Q}$ & $\mathbf{Z}$ & $\mathbf{Q}$ \\
\hline Baureno & 0,614 & 0,263 & 0,124 & 0,345 & $-0,127$ & $-0,471$ & 0,058 & 0,250 & 0,176 & 0,391 \\
\hline Balen & $0,142^{* *}$ & 0,377 & 0,108 & 0,254 & 0,057 & 0,043 & $-0,047$ & $-0,188$ & 0,015 & 0,000 \\
\hline Tretes & $-0,086$ & $-0,182$ & $-0,275^{* *}$ & $-0,900$ & $-0,011$ & 0,000 & $-0,064$ & $-0,212$ & $-0,027$ & $-0,033$ \\
\hline Cawak & $-0,277^{* *}$ & $-0,333$ & $-0,153$ & $-0,273$ & 0,014 & 0,000 & $-0,022$ & 0,000 & $-0,285^{* *}$ & $-0,476$ \\
\hline Jatiblimbing & $-0,212$ & $-0,767$ & 0,075 & 0,233 & 0,096 & 0,268 & 0,085 & 0,416 & $-0,303^{* *}$ & $-1,103$ \\
\hline Kanor & 0,041 & 0,167 & 0,211 & 0,750 & $-0,066$ & $-0,259$ & 0,039 & 0,200 & 0,067 & 0,222 \\
\hline Dander & 0,064 & 0,125 & 0,000 & 0,000 & $-0,174$ & $-0,560$ & 0,101 & 0,389 & $-0,130$ & $-0,313$ \\
\hline Panjang & $-0,138$ & $-0,371$ & $-0,224^{* *}$ & $-0,846$ & $-0,101$ & $-0,400$ & $-0,064$ & $-0,200$ & $-0,223^{* *}$ & $-0,556$ \\
\hline Kerjo & $-0,058$ & 0,623 & $-0,169$ & 0,144 & $-0,062$ & 0,596 & 0,102 & 0,378 & $-0,223$ & 0,052 \\
\hline Klepek & $-0,033$ & $-0,100$ & $-0,062$ & $-0,258$ & 0,087 & 0,182 & 0,076 & 0,263 & $-0,030$ & $-0,095$ \\
\hline Mekuris & 0,019 & 0,000 & $-0,027$ & $-0,063$ & 0,057 & 0,167 & 0,064 & 0,167 & $-0,166$ & $-0,400$ \\
\hline Leran & $-0,408$ & $-2,000$ & $-0,332$ & $-1,394$ & $-0,275$ & $-1,250$ & $-0,290$ & $-1,000$ & $-0,481$ & $-2,286$ \\
\hline Sugihan & 0,09 & 0,13 & 0,019 & 0,045 & 0,052 & 0,000 & $-0,046$ & $-0,222$ & 0,069 & 0,143 \\
\hline Sumberejo & $-0,131$ & $-3,6$ & $-0,067$ & $-0,276$ & $-0,074$ & $-0,242$ & $-0,230^{* *}$ & $-1,261$ & $-0,037$ & $-0,135$ \\
\hline
\end{tabular}

Keterangan: Perubahan signifikan ditandai dengan ** pada taraf kepercayaan $\alpha=0,05$. Nilai Z menunjukkan statistik Mann-Kendall, nilai Q merupakan hasil uji Sen's slope.

Sumber: data diolah dari curah hujan harian (Olah Peneliti, 2019)

Hujan maksimum 5 harian (Rx5hari) memperlihatkan pola penurunan hanya pada stasiun Cawak, Kerjo, dan Leran. Tren tahunan terlihat untuk hujan di atas persentil 95 (P95) pada stasiun Panjang, Mekuris, dan Leran (Gambar 4). Adapun tren untuk nilai hujan sangat lebat (di atas persentil 99, P99) tidak terlihat nyata (Tabel terlampir). Kondisi ini dapat terjadi karena curah hujan di Bengawan Solo Hilir relatif rendah sehingga nilai di atas ambang P99 jarang terjadi setiap musim.

Tren penurunan lebih sering terjadi untuk nilai persentil 95 dibandingkan hujan maksimum 5 harian (Rx5hari). Kondisi ini memperlihatkan hujan kumulatif dalam jangka panjang berpotensi mangalami penurunan pada hampir semua stasiun, terutama bagian timur-selatan. Persentil 95 merupakan gambaran intensitas hujan lebat yang terjadi secara kumulatif dalam rentan musim atau tahunan. Hasil uji Mann-Kendall memperlihatkan intensitas hujan lebat di Bengawan Solo Hilir mengalami penurunan terutama musim penghujan utama (Des-Jan-Feb) dan transisi penghujan-kemarau (Mar-Apr-Mei). Wilayah yang jauh dari pesisir sangat rentan mengalami perubahan pola hujan (Curtis, 2019). Adapun wilayah pesisir cenderung stabil karena mendapatkan suplai uap air dari sirkulasi harian laut-darat. Hal serupa juga terjadi untuk wilayah pegunungan yang mendapatkan efek orografis. Adapun Kabupaten Bojonegoro yang berjauhan dengan peisisir maupun gunung tidak mendapatkan surplus lengas udara dari arah manapun. Akibatnya, ketika terjadi perubahan iklim, wilayah ini akan terus cenderung kering. Kondisi ini dapat semakin parah karena sifat batuan di wilayah selatan bersifat tidak dapat menyimpan air. 

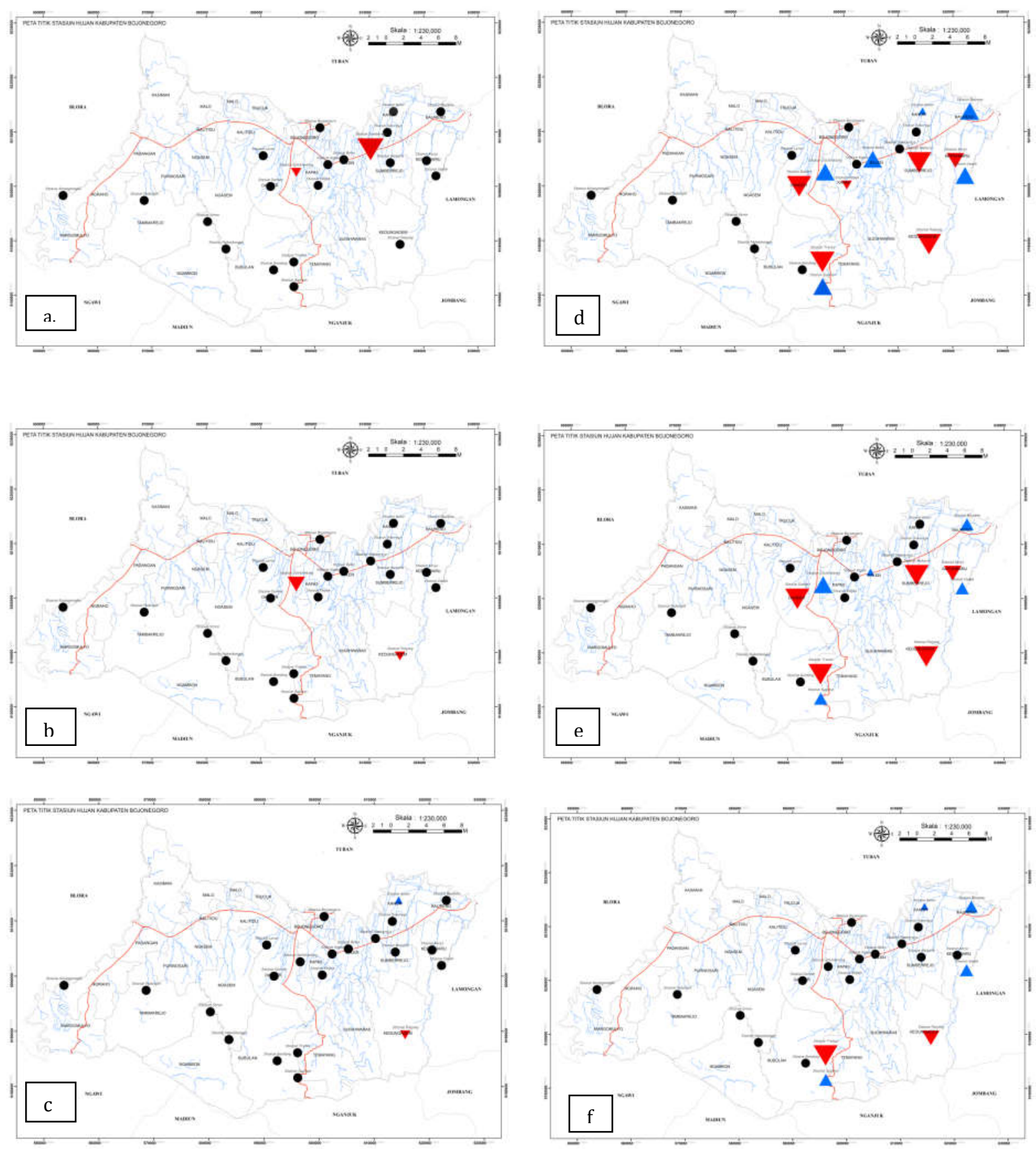

Gambar 4. Tren Hujan Ekstrem Rx5hari (a, b, c) dan P95 (d, e, f). Mulai dari atas ke bawah: tahunan; bulan Des-Jan-Feb; dan Mar-Apr-Mei. Tanda segitga menuniukkan perubahan signifikan.

Kecenderungan penurunan intensitas hujan harian (Simple Daily Intensity) juga terjadi pada stasiun di bagian selatan-timur, antara lain: Bureno, Cawak, Jatiblimbing, Dander, Klepek, Sugihan, dan Sumberejo. Intensitas hujan berkurang terutama pada bulan DesJan-Feb sebagai musim penghujan utama. Hasil penelitian untuk Bengawan Solo Hilir berbeda dengan wilayah Jawa Timur lain, yaitu Kabupaten Pasuruan. Hidayat et al. (2019) memperlihatkan bahwa di Kabupaten Pasuruan tidak terjadi perubahan hujan yang signifikan. Kondisi ini dapat terjadi karena Pasuruan masih dipengaruhi oleh angin laut-darat maupun faktor orografis.

\subsection{Kaitan ENSO dengan Hujan Ekstrem}

Kejadian El Niño/ Southern Oscillation (ENSO) merupakan anomali iklim yang terjadi di Samudera Fasifik sehingga dikenal memengaruhi curah hujan di wilayah Indonesia timur. Identifikasi kejadian ENSO bergantung pada kriteria, indeks yang digunakan, dan tahun dasar. Pada penelitian ini tahun dasar yang digunakan adalah 1981-2010. Nilai indeks seperti SSTA (anomali) merupakan data terstandar sehingga dapat digunakan untuk uji parametrik. 
Tabel 3 Tren of SDII di Bengawan Solo Hilir

\begin{tabular}{|c|c|c|c|c|c|c|c|c|c|c|}
\hline \multirow{2}{*}{ Stasiun } & \multicolumn{2}{|c|}{ Tahunan } & \multicolumn{2}{|c|}{ MAM } & \multicolumn{2}{|c|}{ JJA } & \multicolumn{2}{|c|}{ SON } & \multicolumn{2}{|c|}{ DJF } \\
\hline & $\mathbf{Z}$ & $\mathbf{Q}$ & $\mathbf{Z}$ & $\mathbf{Q}$ & $\mathbf{Z}$ & $\mathbf{Q}$ & $\mathbf{Z}$ & $\mathbf{Q}$ & $\mathbf{Z}$ & $\mathbf{Q}$ \\
\hline Baureno & $0,278^{* *}$ & 0,135 & $0,248^{* *}$ & 0,155 & 0,211 & 0,000 & $0,396^{* *}$ & 0,259 & 0,154 & 0,103 \\
\hline Balen & $-0,147$ & $-0,057$ & $-0,169$ & $-0,133$ & 0,071 & 0,058 & 0,099 & 0,036 & $-0,009$ & $-0,014$ \\
\hline Tretes & 0,008 & 0,002 & 0,103 & 0,066 & $-0,127$ & $-0,068$ & 0,109 & 0,056 & 0,020 & 0,009 \\
\hline Cawak & 0,278 & 0,135 & $0,248^{* *}$ & 0,155 & 0,211 & 0,066 & $0,396 * *$ & 0,259 & 0,154 & 0,103 \\
\hline Jatiblimbing & $-0,296^{* *}$ & $-0,114$ & $-0,089$ & $-0,043$ & $-0,524$ & $-0,657$ & $-0,081$ & $-0,051$ & $-0,314^{* *}$ & $-0,167$ \\
\hline Kanor & $-0,006$ & $-0,006$ & 0,040 & 0,057 & $-0,225$ & $-0,336$ & 0,013 & 0,002 & 0,000 & 0,000 \\
\hline Dander & $-0,248$ & $-0,14$ & $-0,087$ & $-0,058$ & $-0,214$ & $-0,275$ & 0,000 & 0,000 & $-0,347 * *$ & $-0,206$ \\
\hline Panjang & $-0,13$ & $-0,043$ & $-0,128$ & $-0,120$ & 0,000 & $-0,033$ & $-0,119$ & $-0,107$ & $-0,037$ & $-0,008$ \\
\hline Kerjo & $-0,071$ & 0,538 & $-0,039$ & 0,778 & 0,048 & 1,000 & 0,065 & 0,807 & $-0,071$ & 0,563 \\
\hline Klepek & $-0,321$ & $-0,099$ & $-0,148$ & $-0,109$ & $-0,333$ & $-0,115$ & 0,118 & 0,095 & $-0,227^{* *}$ & $-0,081$ \\
\hline Mekuris & $-0,071$ & $-0,033$ & $-0,039$ & $-0,033$ & 0,048 & 0,204 & 0,065 & 0,204 & $-0,071$ & $-0,040$ \\
\hline Leran & $-0,505$ & $-0,413$ & $-0,389$ & $-0,296$ & $-0,238$ & $-0,298$ & $-0,539$ & $-0,394$ & $-0,467$ & $-0,487$ \\
\hline Sugihan & 0,219 & 0,144 & $0,272^{* *}$ & 0,208 & 0,000 & 0,003 & 0,037 & 0,094 & $0,254 * *$ & 0,160 \\
\hline Sumberejo & 0,219 & 0,144 & $0,272 * *$ & 0,208 & 0,000 & 0,003 & 0,037 & 0,094 & $0,254 * *$ & 0,160 \\
\hline
\end{tabular}

Keterangan: Perubahan signifikan ditandai dengan ** pada taraf kepercayaan $\alpha=0,05$. Nilai Z menunjukkan statistik

Mann-Kendall, nilai Q merupakan hasil uji Sen's slope.

ENSO positif terjadi pada 1982, 1983, 1986, 1987, 1991, 1992, 1994, 1997, 1998, 2002, 2009, 2015,2016 . Tahun 1983, 1984, 1985, 1988, 1989, 1995, 1998, 1999, 2000, 2007, 2008, 2010, 2011 terjadi ENSO negatif. ENSO positif kuat terjadi pada tahun 1982-1983, 1997-1998, dan 2015-2016. ENSO negatif kuat terjadi pada 1988, 1989, 2000, 2007, dan 2010. Hasil tersebut berbeda dengan analisis dari Lestari et al. (2019). Perbedaan terjadi karena indeks yang digunakan tidak sama dan ketidaksamaan dalam pendefinisian ENSO. Sebagian besar kejadian ENSO dimulai bulan Mei-Juni-Juli, yang mana bersamaan dengan bulan kemarau di Indonesia. Efek ENSO positif yang terjadi saat musim kemarau sulit diprediksi karena curah hujan relatif rendah.

Tabel 4 Korelasi Spearman SSTA Nino 3.4 dengan RX1hari dan Rx5hari

\begin{tabular}{|c|c|c|}
\hline \multirow{2}{*}{ Stasiun } & \multicolumn{2}{|c|}{ ENSO } \\
\hline & R1max & R5max \\
\hline Balen & $-0,153$ & $-0,205$ \\
\hline Baureno & $-0,196$ & $-0,201$ \\
\hline Cawak & $-0,082$ & $-0,088$ \\
\hline Dander & $-0,190$ & $-0,210$ \\
\hline Jatiblimbing & $-0,182$ & $-0,203$ \\
\hline Kanor & $-0,183$ & $-0,187$ \\
\hline Kerjo & $-0,086$ & $-0,109$ \\
\hline Klepek & $-0,185$ & $-0,171$ \\
\hline Leran & $-0,099$ & $-0,137$ \\
\hline Mekuris & $-0,123$ & $-0,115$ \\
\hline Panjang & $-0,120$ & $-0,104$ \\
\hline Sugihan & $-0,215$ & $-0,191$ \\
\hline Sumberejo & $-0,161$ & $-0,187$ \\
\hline Tretes & $-0,141$ & $-0,144$ \\
\hline
\end{tabular}

Sumber: olah data peneliti, 2019. Angka cetak tebal dan miring menunjukkan signifikan pada taraf $\alpha=0,05$
Hubungan antara hujan ekstrem Rx1hari dengan indeks SSTA Nino 3.4 signifikan di hampir semua lokasi, meskipun tingkat hubungan adalah lemah (Tabel 4). Hasil negatif menunjukkan bahwa indeks positif berasosiasi dengan curah hujan ekstrem rendah. Koefisien rendah pada uji Spearman menjadi indikasi bahwa hujan ekstrem yang terjadi pada skala harian sulit diidentifikasi menggunakan indeks ENSO, meskipun terlihat adanya hubungan antara ENSO dengan RX1hari. Ekstrem dalam satu hari di wilayah tropis berkaitan erat dengan kondisi cuaca dan sirkulasi angin harian.

Hal serupa juga terjadi pada korelasi antara indeks ENSO dengan Rx5hari, yang mana hampir semua stasiun memperlihatkan hubungan dengan taraf nyata. Nilai korelasi Rx5hari - SSTA lebih tinggi dibandingkan dengan Rx1hari-SSTA Nino 3.4 dengan selisih rerata adalah $(\rho)$ sebesar 0,02. Kedua uji tersebut mengindikasikan bahwa pengaruh ENSO terhadap curah hujan ekstrem terjadi pada skala kumulatif (bulanan atau musiman). Hubungan antara hujan musiman maupun tahunan dengan ENSO lebih menggambarkan variabilitas tahunan. ENSO sendiri memang dikenal sebagai faktor eksternal variabilitas tahunan; adapun monsun adalah variabilitas antarmusim di Pulau Jawa. Pengaruh antara ENSO dengan kejadian ekstrem akan sulit diidentifikasi untuk skala pendek. Artinya adalah, ENSO tidak dapat dijadikan sebagai parameter kejadian ekstrem hidrometeorologi pada skala < 5hari. Kajian yang dilakukan oleh Hidayat dan Ando (2014) memperlihatkan bahwa ENSO dan IOD bekerja bersama-sama pada wilayah Jawa bagian barat, akan tetapi untuk wilayah timur cukup menggunakan parameter ENSO.

Kondisi ini dapat dijelaskan dalam penelitian Villafuerte dan Matsumoto (2015) bahwa curah hujan harian berkaitan dengan kondisi awan dan sirkulasi harian. ENSO memang berpengaruh pada peningkatan 
atau penurunan hujan ekstrem harian, akan tetapai sirkulasi lokal lebih berperan dalam penentuan hujan harian. Hujan harian ekstrem untuk wilayah Jawa bagian barat sangat terpengaruh oleh siklus Madden Julian Oscillation (MJO) yang membawa angin basah (Aldrian, 2008; Lestari et al., 2019). Akan tetapi, faktor yang memengaruhi hujan ekstrem di Jawa bagian timur belum pernah diidentifikasi oleh peneliti lain. Apabila dilihat dari pergerakan MJO, Jawa bagian timur tidak terpengaruh oleh MJO maupun IOD.

Identifikasi ENSO dan IOD kemungkinan lebih tepat digunakan untuk analisis perubahan lama hari hujan berturut-turut (Consecutive Wet Days- CWD) atau lama hari tidak hujan (Consecutive Dry Days CDD). Kedua indeks tersebut menggambarkan nilai kumulatif dari hujan. Hasil analisis mengunakan tiga stasiun uji menunjukkan korelasi ENSO-CDD lebih tinggi dibandingkan dengan data curah hujan musiman (kumulatif).

Penelitian ini mengungkap bahwa identifikasi indeks perlu dilakukan lebih seksama terutama karena monsun di Pulau Jawa merupakan variabilitas antarmusim. Apabila ENSO terjadi pada musim kemarau maka efeknya lebih sulit dikenali. Penulis menyarankan penggunaan data dasarian untuk melengkapi kekurangan pada penelitian ini.

\section{Kesimpulan}

Curah hujan ekstrem di Bengawan Solo Hilir mengalami penurunan berarti terutama pada pada indeks Rx1hari, P95, dan intensitas hujan harian. Penurunan hujan harian maksimum berkisar antara 0,3 mm/tahun - 1,1 $\mathrm{mm} /$ tahun. Stasiun yang memperlihatkan perubahan didominasi bagian timur dan selatan, yang mana wilayah tersebut rentan terhadap kekeringan. Kejadian hujan ekstrem di Bengawan Solo Hilir berkaitan dengan kejadian ENSO, meskipun hubungannya lemah. Efek ENSO terhadap hujan lebih tepat digunakan untuk data dasarian, bulanan, maupun antarmusim.

\section{UCAPAN TERIMA KASIH}

Penelitian ini didanai oleh Kemenristekdikti melalui skema Penelitian Dosen Pemula (PDP) tahun anggaran 2019 dengan nomor kontrak 036/SP2H/LT/MOMO/L7/2019.

\section{DAFTAR PUSTAKA}

Aldrian, E. 2008. Dominant Factors of Jakartas Three Largest Floods. J. Hidrosfir Indonesia, 3 (3): 105 - 112. ISSN 1907-1043.

Badan Perencanaan Pembangunan Nasional (Bappenas). 2010. Indonesia Climate Change Sectoral Roadmap tahun 2010.

Curtis, S. 2019. Means and Long-Term Trends of Global Coastal Zone Precipitation. Scientific Reports, 9: 5401. DOI: 10.1038/s41598-019-41878-8
ETCCDI. 2017. Climate Change Indices. http://etccdi.pacificclimate.org/list_27_indices.shtml

Goswani, B.N., V. Venugopal, D. Sengupta, M.S. Madhusoodanan, P.K. Xavier. 2006. Increasing Trend of Extreme Rain Events Over India in a Warming Environment. Science, 314: 1442-1445.

Hidayat, M.D.,N., Indarto, M. Askin, I. Andriyani, Tasliman. 2019. Kecenderungan Hujan Ekstrem di Unit Pelaksana Teknis Pengelolaan Sumberdaya Air di Pasuruan, Jawa Timur. Jurnal Ilmu Lingkungan Vol. 43 (1) : 21 - 31. ISSN: 1410-7244.

Hidayat, R., dan K. Ando. 2014. Variabilitas Curah Hujan Indonesia dan Hubungannya dengan ENSO/IOD: Estimasi Menggunakan Data JRA-25/JCDAS. Jurnal Agromet Indonesia 28 (1): 1-8. DOI: 10.29244/j.agromet.28.1.1-8.

Kementerian Pekerjaan Umum Ditjen Sumber Daya Air BBWS Bengawan Solo. 2019. Wilayah Administratif Bengawan Solo. http: //sda.pu.go.id/bbwsbengawansolo/portal/index.php /wilayah-administratif-2/ diakses pada 24 Desember 2019.

Keputusan Presiden No. 12 Tahun 2012 tentang Penetapan Wilayah Sungai.

Lestari, S., A. King, C. Vincent, D. Karoly, A. Protat. 2019. Seasonal Dependence of Rainfall Extremes in and around Jakarta, Indonesia. Weather and Climate Extremes $24 \quad$ : $100202 . \quad$ DOI: 10.1016/j.wace.2019.100202.

Pemerintah Daerah Kabupaten Bojonegoro. 2015. Rencana Pembangunan Jangka Menengah Daerah (RPJMD) (Perubahan) 2013 - 2018.

Peterson, T.C. 2005. Climate Change Indices. WMO Bulletin 54: 83-86.

Salmi, T., A. Määttä, P. Anttila, T. Ruoho-Airola, T. Amnell. 2002. Detecting Trends of Annual Values of Atmospheric Pollutans bye the Mann-Kendall Test and Sen's Slope Estimates - The Excel Template Application Makesens. Finnish Meteorological Institute, Helsinki.

Siswanto, Supari. 2015. Rainfall Changes over Java Island, Indonesia. Journal of Environment and Earth Science $\mathbf{5}$ (14): 1-9.

Supari, Sudibyakto, J. Ettema, E. Aldrian. 2012. Spatiotemporal Characteristics of Extreme Rainfall Events over Java Island, Indonesia. Indonesian Journal of Geography 44 (1): 62-86. DOI: 10.22146/indo.j.geog.2391.

Trenberth, K.E. 2011. Changes in Precipitation with Climate Change. Climate Research 47: 123-138.

Van den Hurk, B, and D. Jacob. 2009. The Art of Predicting Climate Variability and Change. Climate Change Adaptation in the Water Sector: 9-22.

Villafuerte II, M.Q., J. Matsumoto. 2015. Significant Influence of Global Mean Temperature and ENSO on Extreme Rainfall in Southeast Asia. Journal of Climate 28 (5): 1905-1919. DOI: 10.1175/JCLI-D-14-00531.1.

Zhang, X., L.V. Alexander, G.C. Hegerl, P. Jones, A. Klein Tank, T.C. Peterson, B. Trewin, F.W. Zwiers. 2011. Indices for Monitoring Changes in Extremes Based on Daily Temperature and Precipitation Data. WIREs Climate Change 2(26): 851 - 870. DOI: 10/1002/wcc.147. 